\title{
SELP wt Allele
}

National Cancer Institute

\section{Source}

National Cancer Institute. SELP wt Allele. NCI Thesaurus. Code C51191.

Human SELP wild-type allele is located within $1 \mathrm{q} 24.2$ and is approximately $41 \mathrm{~kb}$ in length.

This allele, which encodes P-selectin protein, plays a role in platelet activation and degranulation. 